Research Article

\title{
Increasing the Efficiency of Detailed Soil Resource Mapping on Transitional Volcanic Landforms Using a Geomorphometric Approach
}

\author{
Ahmad Priyo Sambodo ${ }^{1}{ }^{1}$ and Tanwa Arpornthip $\mathbb{D}^{1,2}$ \\ ${ }^{1}$ Faculty of Technology and Environment, Prince of Songkla University, Phuket Campus, Phuket 83120, Thailand \\ ${ }^{2}$ Andaman Environment and Natural Disaster Research Center (ANED), Prince of Songkla University, Phuket Campus, \\ Phuket 83120, Thailand \\ Correspondence should be addressed to Tanwa Arpornthip; tanwa.a@phuket.psu.ac.th
}

Received 13 August 2020; Revised 29 April 2021; Accepted 6 May 2021; Published 31 May 2021

Academic Editor: Evgeny Abakumov

Copyright (c) 2021 Ahmad Priyo Sambodo and Tanwa Arpornthip. This is an open access article distributed under the Creative Commons Attribution License, which permits unrestricted use, distribution, and reproduction in any medium, provided the original work is properly cited.

\begin{abstract}
For developing countries, detailed soil resource data and maps are essential in land-use planning. Unfortunately, obtaining detailed soil data for mapping is expensive. Detailed soil studies and mapping in developing countries often use the grid method. In addition to being time-consuming, the grid method needs a lot of sample points and surveyors. Geomorphometry can be a less expensive alternative for detailed soil mapping. Geomorphometry uses computationally measured terrain characteristics to describe other hard-to-measure terrain and soil properties. In our study, landform arrangements and slopes were analyzed together to create a map of soil $\mathrm{pH}$. Bompon watershed, Indonesia, was used as a case study. Soil mapping units with potentially similar soil $\mathrm{pH}$ were created based on a classification system of the two geomorphometric parameters. Soil samples were taken from each of the units. The samples' soil pH was measured and compared to the geomorphometric predicted result. Regression tests were performed to see the significance of geomorphometric parameters on soil $\mathrm{pH}$ conditions. Regression tests show that the results of $p$ value of the four soil layers are $0.046,0.019,0.037$, and 0.047 , respectively, on a $5 \%$ confidence level. According to the test result, landform arrangements and slopes can indicate soil $\mathrm{pH}$ conditions in Bompon. Our estimate suggests that our geomorphometric method is cheaper than the grid method by a factor of seven. The ability to use geomorphometric parameters to describe other soil properties could enable a cheap and fast production of detailed soil maps for developing countries.
\end{abstract}

\section{Introduction}

Detailed soil maps are essential for developing countries. The development process, especially in agriculture, needs detailed soil maps for planning, maintaining, and conservation [1-4]. The absence of detailed soil maps could lead to devastating results. Soil erosion, landslide, soil degradation, and productivity reduction are examples [5-7]. These negative consequences could slow down the economy and threaten food security $[5,8]$. Thus, developing countries' efficient economic development should have a detailed soil map as a base for planning.

Detailed soil maps in developing countries are still hampered by the costs [9]. The expensive costs are a challenge for soil maps' usability in the development process
[10-12]. The expensive costs are a result of using the grid method. Many of the developing countries make the grid method a standard method for soil mapping. The grid method divides the research or project area into grids based on the mapping scale. In general, more detailed scales require smaller grid sizes. Thus, a detailed soil map needs more samples [10-12]. A large number of samples are expensive to acquire. The grid method can also be less objective, especially in drawing grid borders [13].

To reduce the cost, soil scientists start to use geomorphometry to demarcate soil mapping units. Geomorphometry is a study about the quantitative aspect of a landform, or quantitative geomorphology, by analyzing mathematical data extracted from digital elevation models [14-16]. Facilitated by the widespread use of geographic 
information systems (GIS), studies on geomorphometry for soil mapping have become more mature. De Bruin and Stein [17] used the elevation, slope, profile curvature, plan curvature, wetness index, stream power index from a digital elevation model (DEM) data with a resolution of 5 meters to perform soil-landscape modelling in Southern Spain. Trevisani et al. [18] experimented with the anisotropy index, relative roughness, roughness, and integral of the variogram parameters of the LiDAR data to see surface soil textures in the Masiaga Basin covering an area of $4.54 \mathrm{~km}^{2}$ in Italy. Other studies from Viloria et al. [19] in north-central Venezuela mountains used altitude, relative height, slope gradient, aspect, profile curvature, and five other modelling parameters landscape-soil relationships. Gopp et al. [20] used 17 morphometric parameters obtained from ASTER GDEM with a 30-meter resolution to view the soil's spatial variability in Western Siberia.

Broader geomorphometric applications still need more research, especially in dynamic regions. Previous studies have not focused on tropical and volcanic regions [21-24]. Volcanic landform on a tropical climate has a dynamic geomorphic process [25]. Those dynamic processes could result in a unique and specific soil. Another challenge is the use of many parameters and methods $[19,20,26]$. The use of many parameters can make result interpretation complex and challenging, reducing the applicability of geomorphometry. Additionally, high-quality GIS data might not be available in developing countries. Lastly, previous studies use a small scale in a large area $[19,23,26,27]$. During mapping on a small scale, the generalization often eliminates small but essential aspects of the landforms. In many developing countries, these small, specific, and unique problems could affect huge populations. Those are the limitations that reduce the use of geomorphometry on soil mapping.

A transitional volcanic landform is a unique, specific, and geomorphologically dynamic region. Transitional volcanic landforms situate between a quarter volcanic complex and the tertiary volcano complex [28, 29]. Soil development in transitional volcanic regions results from geomorphological processes that are dynamic, different, and unstable [25]. The soil of transitional volcanic landforms tends to have unique and specific soil characteristics [29]. In addition to weathering due to the climate, soils in the volcanic transition region are also derived from volcanic breccia rocks distorted by the tertiary era's magma intrusion process $[29,30]$. Complex soil development processes produce a deep layer of soil and weathered material with high clay content [30-32]. Additionally, a transitional volcanic landform has dynamic land movement processes, such as landslides and high erosion [28, 30, 33-35].

Our study suggests the possibility of using geomorphometric parameters to create a detailed soil map in a transitional volcanic area. The application of geomorphometry on a detailed scale could replace the standard grid method for soil mapping in developing countries. Specifically, our study shows that geomorphometric parameters can determine some soil characteristics with statistical significance, even at a detailed scale. Specifically, the parameters used in the study are the landform arrangements and the slopes. The soil characteristic determined from geomorphometry is the soil $\mathrm{pH}$ level. Geomorphometry can provide a cost-efficient alternative to the standard grid method. Furthermore, the success of the study in applying geomorphometry in a transitional volcanic landform suggests that the method can be used even in areas with a dynamic geomorphology configuration, specific soil characteristics, and intense geomorphology processes.

\section{Materials and Methods}

2.1. Study Area. The study area is the Bompon watershed. The watershed sits on a transitional volcanic area between Mount Sumbing (Quartenary) and Kulonprogo Mountain Range (Tertiary). The Bompon watershed has an estimated area of 300 hectares. It is located in the Salaman and Kajoran subdistricts, Magelang District, Central Java Province (Figure 1). The Bompon watershed is in a tropical climate region with annual rainfall reaching $2500 \mathrm{~mm}$ /year. The peak of the rainfall is in November-January. Around 2500 people live in the Bompon watershed. Accessibility is still poor. Some areas still have a gravel small road that limits access during rainy seasons.

Land use in the Bompon watershed is varied along the area. The upper part of Bompon is dominated by mixed farms. The main commodities are sengon (Albizia Chinensis) and coconut. Some cassava plantations can be found in small patches. On the flat area near the Bompon river, the land is being used for paddy fields with two different systems. The southern part with low elevation uses irrigation systems, whereas the higher northern part uses rain-fed systems.

The Bompon watershed sits between Quaternary Sumbing volcano and the tertiary Kulonprogo volcanic range. The watershed is considered to be a transitional volcanic landform. The soil covering the Bompon watershed is formed from weathering volcanic ash of a Sumbing volcano, with a thickness of up to 2 meters. Meanwhile, the layers beneath it are hydrothermal alteration processes of the volcanic breccia material era due to the magmatic intrusion process of the Kulonprogo volcanic range in the tertiary era. As a result, thick soil in the Bompon watershed is easily eroded. It is also prone to landslides due to the absence of compact material that can be grabbed by plant roots. Such conditions make the Bompon watershed and, in general, a volcanic transition landform a very unique and suitable location for our study.

\section{Methodology}

To show that geomorphometry can be used to create a detailed soil map that is more cost-efficient than the standard grid method, our study is divided into four steps: creating soil mapping units, soil sampling, soil analysis, regression analysis, and cost comparison. Figure 2 shows the flowchart of the methodology.

In the first step, the entire area of the Bompon watershed is demarcated into soil mapping units. 


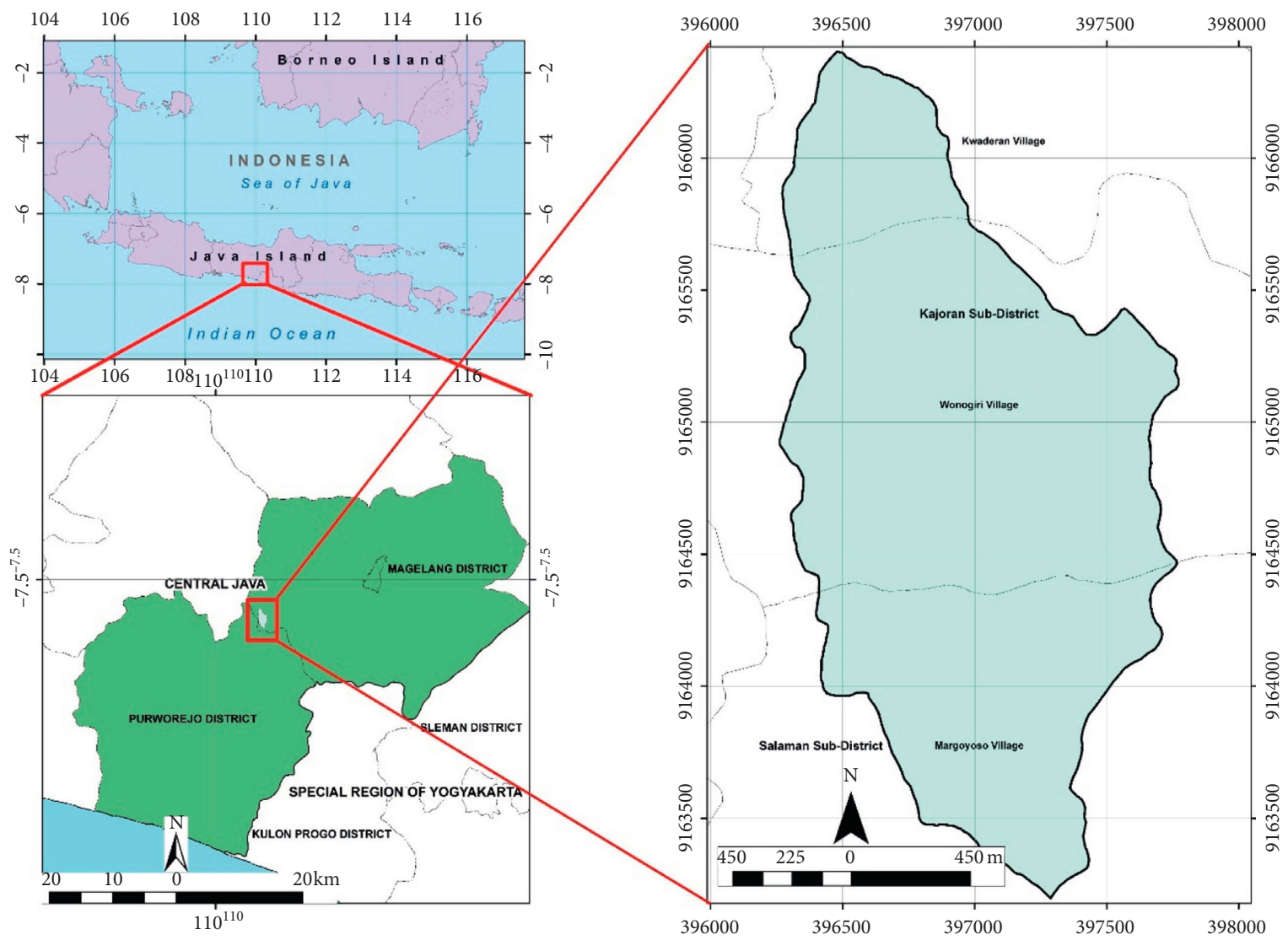

FIgURE 1: Location of Bompon watershed. Sits near the border between Magelang and Purworejo District, Central Java, Indonesia.

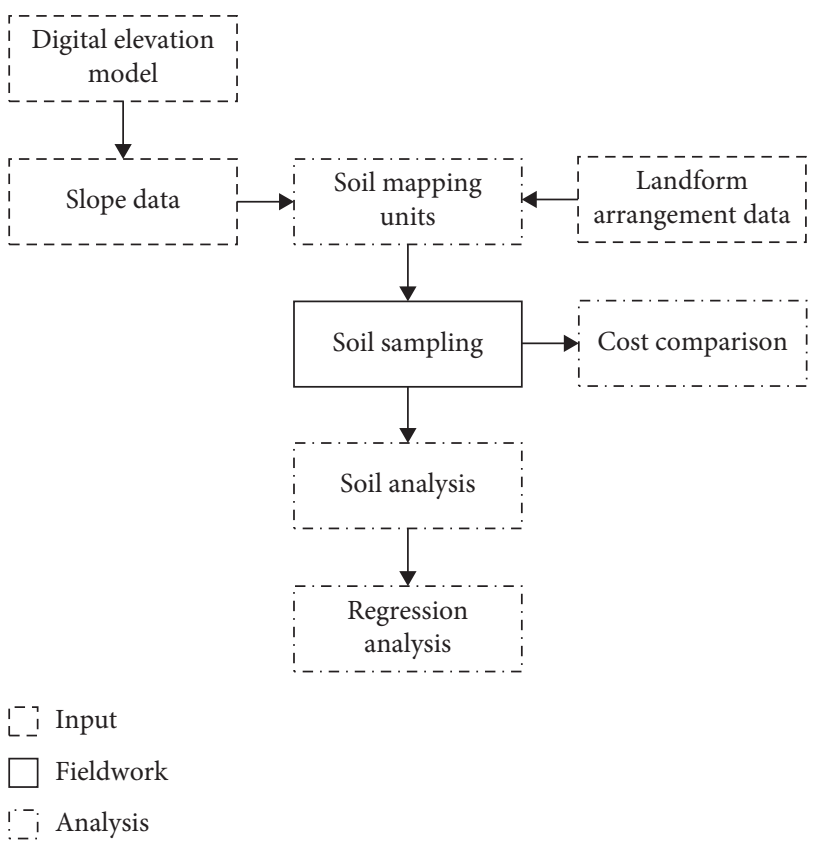

FIGURE 2: The flow of the research is divided into three parts: (1) data input, (2) fieldwork, and (3) analysis.

Geomorphometric parameters are used to determine the boundary of a mapping unit. The area within a mapping unit has similar geomorphometric parameters. For our study, the topography is used to determine the boundary of mapping units. This is based on the theory of soil formation which states that one of the main factors forming soil is topography [36]. Soil Catena principles also suggest the topography conditions strongly influence the soil distributions [12, 37-39].

The significance of topography in determining soil characteristics can also be explained by two major theories regarding soil formation: Jenny's theory and the SCORPAN approach $[10,12,36]$. Both theories suggest many factors that can affect soil characteristics. Jenny's theory indicates that the climate, organism activities, parent rocks, the topography, and the passage of time can affect soil characteristics. The SCORPAN approach extends Jenny's theory and includes the soil itself and geographic locations as additional factors.

For geomorphometry research, not all parameters can be used. The practicality of acquiring the data, the availability of the data, the homogeneity of the research area should be matched with the aim of the research. For example, due to the size of the study area, the climate factor would be unsuitable, as it would be homogenous over the small area of interest [31, 32]. Similar reasoning is applied for parent material and time. Additionally, organism and human activities are too complex for the study. The use of organism and human activities would also significantly increase the cost of the geomorphometry method, thus erasing most of the benefits of using it. 
The topographical data used in our study are the landform arrangements and the slope. Both parameters have a significant effect on soil characteristics. The landform arrangement divides the landform into several classes according to the deviation from the mean elevation of the area [40]. Landform arrangement classes can explain the soil development and distribution of an area [5, 41-43]. Soil Catena's theories also link the distribution of soil and its properties with landform arrangements and its topo-sequence $[12,37-39]$. On a general scale, classification according to landform arrangements can cover multiple topographical data, such as elevation, curvatures, aspect, and local relief.

In addition to the landform arrangements, the slope is an important quantitative parameter of the landform [44]. Slope also affects the soil development process, especially in tropical regions. Slope affects processes such as soil erosion, landslide, material deposition, alluviation, and leaching $[5,45,46]$. A soil process modelling, like USLE and WEPP, also relies on the slope as one of the main parameters $[47,48]$.

With the widespread use of digital elevation models (DEMs), the combination of landform arrangement and slope data should be simple to acquire. Both parameters come from different datasets and methods. Arrangement data is the secondary data obtained from the Transbulent research group, Gadjah Mada University. Arrangement data is derived from a DEM with a 12.5-meter resolution. Meanwhile, the slope data is derived from the Indonesian national seamless DEM (DEMNAS) published by the Indonesian Geospatial Agency (BIG) in 2018 with an 8.5-meter resolution. Both resolutions are suitable for a study at a scale smaller than $1: 10000$ [49]. Combining the arrangement and the slope data and grouping land area with similar topographical data help determine the boundary of each soil mapping unit.

In the second step, soil samples were acquired and tested. In contrary to the standard grid method, in which soil samples are required over the entire area, a geomorphometry method only requires a few samples from each of the mapping units. Thus, the geomorphometry method simplifies and lessens the amount of work needed to collect soil samples.

At each sampling location, a soil profile was made to take samples. Each profile has a maximum depth of $150 \mathrm{~cm}$. The maximum depth is based on the recommendation by the USDA, as well as the depth of the base material in the Bompon watershed $[3,40]$. Within a profile, each soil layer is sampled separately. Colors, structures, textures, moisture levels, and rooting zones differentiate soil layers within a profile [2, 3, 40]. In total, 124 soil profile samples were obtained (Figure 3).

The number of samples taken during soil research has varied considerations and mainly depends on the research objective and goals. Some natural factors such as geomorphology configuration are commonly used as considerations, especially on modern soil mapping $[3,52,53]$. In fact, technical and practical reasons such as accessibility, safety, time, and even cost are also commonly used as considerations $[12,54,55]$. Previous research about soil characteristics tends to have multiple considerations for determining the amount of sample. Elnaggar and Noel [56] made research to see salt-affected soil with 210 samples to cover about $1160 \mathrm{~km}^{2}$ area. Different research about soil salinity by Eishoeei et al. [57] used 8 soil profiles on a $4750 \mathrm{~km}^{2}$ area. Research about soil parent materials by Richter et al. [58] used in total 60 samples on an $8,9 \mathrm{~km}^{2}$ area. There is also much research using a small amount of sample to cover a large area or the opposite [59-63]. In conclusion, in general soil research, the amounts of samples will be different from each other, because of the specific conditions and research factors.

The amounts of samples taken for this research are determined by using common guidelines for soil mapping. The general guidelines to produce a reliable soil map are commonly based on the observation density per $\mathrm{cm}^{2}$ area on the map, or representing per $\mathrm{km}^{2}$ on the field [53] (Tables 1 and 2).

Based on both recommendations, samples taken for this research are about 120 sampling points (Figure 3 ). With the area around $3 \mathrm{~km}^{2}$, the sample density on this research is 40 samples $/ \mathrm{km}^{2}$; its sufficient to produce a reliable soil map based on both recommendations above.

In the third step, the soil samples are analyzed for their $\mathrm{pH}$ level. As mentioned above, geomorphometric data are used to determine soil $\mathrm{pH}$ levels at different locations. In order to test the validity of the geomorphometric method, measured $\mathrm{pH}$ level values are needed for comparison.

Soil $\mathrm{pH}$ is a simple but important parameter to understand soil resources. Naturally, the acidity or alkalinity of the soil reflects the physical, chemical, and biological characteristics of the soil $[3,4,50]$. In agricultural fields, soil $\mathrm{pH}$ is one of the most important parameters to determine soil suitability for plant growth $[5,51-54]$. Soil $\mathrm{pH}$ is also sensitive to human interference such as irrigation method, land-use change, soil overutilization, toxification, and salinization [55-57].

For this research, there are two types of $\mathrm{pH}$ used which are actual and potential $\mathrm{pH}$. The amount of sample needed is around 1 gram each. Soil sample is then diluted on the reaction tube using two kinds of solution, $\mathrm{H}_{2} \mathrm{O}$, or pure water for actual $\mathrm{pH}$ and $\mathrm{KCl}$ for potential $\mathrm{pH}$ with a $1: 1$ ratio [64]. The $\mathrm{pH}$ test strip is then dipped into the solution after the soil particle settles at the bottom of the tube. After the result came, the $\mathrm{pH}$ value will be classified based on USDA $\mathrm{pH}$ classifications (Table 3) [2, 3, 53].

In the fourth step, the statistical significance between geomorphometric parameters and the $\mathrm{pH}$ level is determined. To determine whether the arrangement and the slope data can determine the $\mathrm{pH}$ level with statistical significance, a simple linear regression was used. The level of statistical significance was determined using null hypothesis testing with the level of significance of 0.05 . The regression test was performed for each landform arrangement and slope configurations.

In the last step, the cost of performing the standard grid method was compared with the cost of performing the geomorphometry method. For each method, the number of 

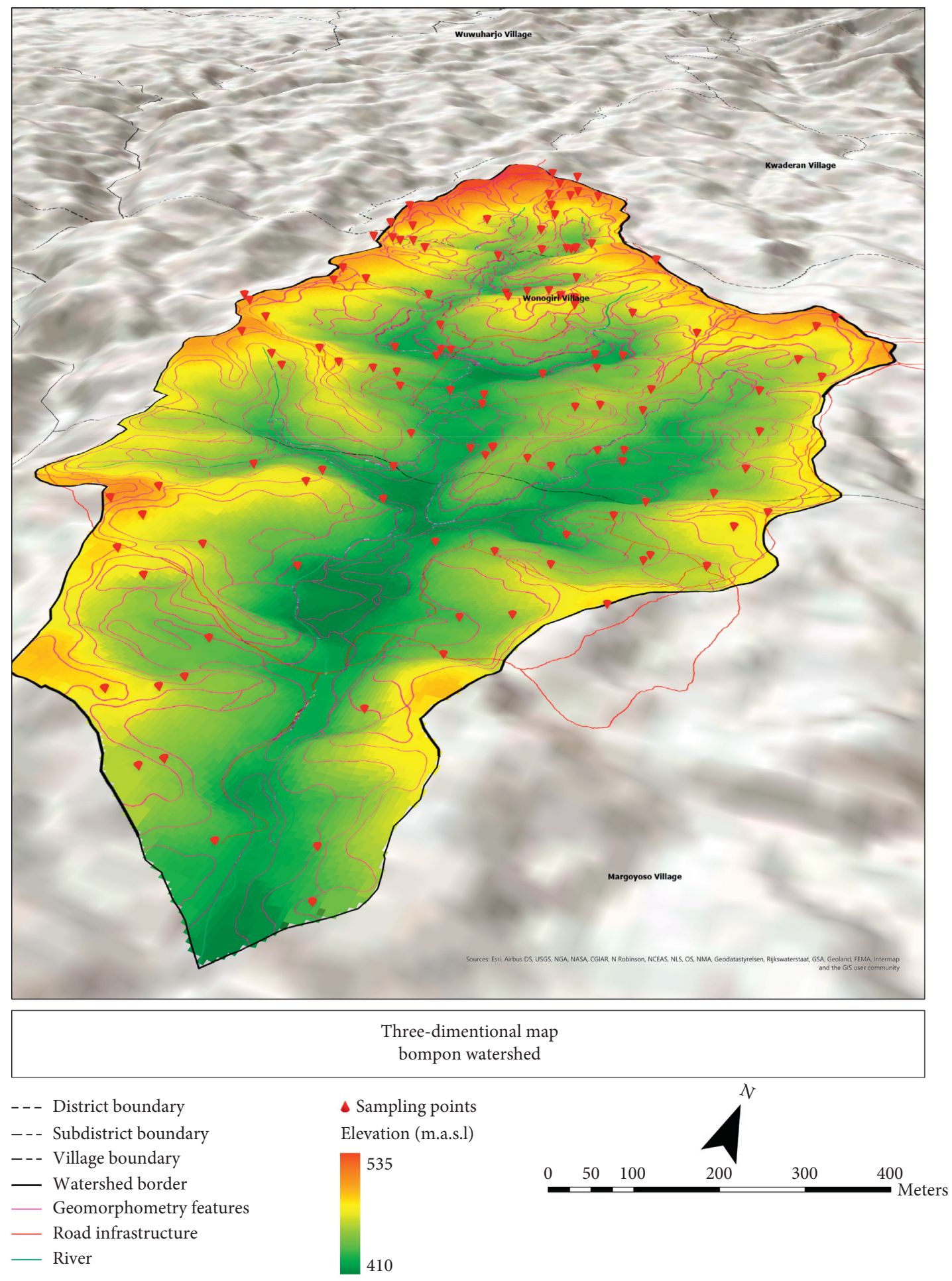

FIGURE 3: Soil sample distributions in the research area. In total, there are 124 soil sampling points on Bompon watershed. At each location, the soil profile was observed and divided into several layers before taking the soil samples. Differences in sampling density are caused by a difference in the geomorphometry setting on the area.

samples needed, the amount of personnel involved, the time taken at each sample site, and the logistics cost for the work were taken into account. The estimates for the grid method came from previous works of the Transbulent research group. The estimates for the geomorphometry method were from the current study.

\section{Results and Discussion}

4.1. Soil Mapping Units. Based on the 2015 survey data by the Transbulent research group, the Bompon watershed can be divided into 6 different landform arrangements: interfluve, upper slope, middle slope, lower slope, colluvial 
TABLE 1: Soil sampling density per $\mathrm{km}^{2}$ mapping area.

\begin{tabular}{lccc}
\hline Scale & \multicolumn{2}{c}{ Recommended range } & $\begin{array}{c}\text { Minimum acceptable range } \\
0.25 / \mathrm{cm}^{2} \text { density on a map }\end{array}$ \\
\hline $1: 5.000$ & $1 / \mathrm{cm}^{2}$ density on a map & $0.5 / \mathrm{cm}^{2}$ density on a map & 100 \\
$1: 10.000$ & 400 & 200 & 25 \\
$1: 25.000$ & 100 & 50 & 4 \\
$1: 50.000$ & 16 & 8 & 1 \\
$1: 100.000$ & 4 & 2 & 0.25 \\
$1: 250.000$ & 1 & 0.08 & 0.04 \\
$1: 500.000$ & 0.16 & 0.02 & 0.01 \\
\hline
\end{tabular}

TABLE 2: Recommended intensities of soil investigation.

\begin{tabular}{lc}
\hline Scale & Site and soil profile descriptions \\
\hline $1: 1.000$ & $10-20 / \mathrm{ha}$ \\
$1: 5.000$ & $0.5-1 / \mathrm{ha}$ \\
$1: 10.000$ & $10-20 / \mathrm{km}^{2}$ \\
$1: 25.000$ & $1.5-3 / \mathrm{km}^{2}$ \\
$1: 50.000$ & $0.5-1 / \mathrm{km}^{2}$ \\
$1: 100.000$ & $0.1-0.2 / \mathrm{km}^{2}$ \\
\hline
\end{tabular}

TABLE 3: pH Classifications by USDA.

\begin{tabular}{lc}
\hline $\mathrm{pH}$ value & Classification \\
\hline $3,5-4,4$ & Extremely acid \\
$4,5-5,0$ & Very strongly acid \\
$5,1-5,5$ & Strongly acid \\
$5,6-6,0$ & Moderately acid \\
$6,1-6,5$ & Slightly acid \\
$6,6-7,3$ & Neutral \\
$7,4-7,8$ & Slightly alkaline \\
$7,9-8,4$ & Moderately alkaline \\
$8,5-9,0$ & Strongly alkaline \\
\hline
\end{tabular}

footslope, and colluvial plain. The results of slope classes processing from the DEM data with a resolution of 8.5 meters show that the flattest slope is less than $1 \%$ and the steepest is $60 \%$. The dominant slope range is between $15 \%$ and $30 \%$, which corresponds to the "hilly" classification using the USDA system. Around $67 \%$ of the total area of the Bompon watershed $(196,410$ hectares) falls within the dominant slope range (Figure 4).

Slopes of $15 \%-30 \%$ are distributed evenly in the Bompon watershed, even in the interfluve area or watershed boundaries. The slope configuration is influenced mostly by landslides. Landslides are geomorphologically gravitational processes. Areas that have geomorphologically dominant gravitational processes will have a maximum slope of $30 \%$. Steeper slopes are unstable and prone to landslides [58-60]. The results of the gravitational processes are strongly reflected in the morphological form of the Bompon watershed. The concaveconcave spoon-like shape of the watershed is an indicator of such processes taking place [72]. Another factor influencing the morphometry of the Bompon watershed is the lack of hard rock/lithological contact. The lack of lithological contact resulted in moderately steep slopes, even with intense erosion and mass movement.
4.2. Soil Samples and Analysis. A total of 124 soil samples were taken. The $\mathrm{pH}$ values of the samples were measured. Most of the soil samples have $\mathrm{pH}$ values between 4.6 and 6.6 (Figure 5). The distribution of soil $\mathrm{pH}$ skews more acidic. The acidity of the soil is a natural phenomenon for volcanic regions with high rainfall intensity [74]. Two main natural factors affecting the soil $\mathrm{pH}$ are the climate and mineral content of the parent material. The quarter volcanic material of Mount Sumbing, the parent material of soil in Bompon, is rich in iron $(\mathrm{Fe})$. The oxidation process of $\mathrm{Fe}$, from rainfall weathering, releases $\mathrm{Fe}^{3+}$. The positive iron decreases the soil $\mathrm{pH}$. The high rainfall also intensifies the leaching process of the alkaline minerals such as Magnesium [54, 55]. The absence of carbonate materials in Bompon further reduces the $\mathrm{pH}$ value.

Considered as layers, soil $\mathrm{pH}$ values in the Bompon watershed show a similar acidic-biased distribution. The difference in soil pH values across layers is not drastic. Even though the high rainfall would typically create a larger difference across layers, the high clay content of Bompon reduces such effect. Clay tends to maintain its chemical properties, including $\mathrm{pH}$ [75]. The small particle size of clay and the high CEC values reduce water movement through pores, thus slowing down the leaching process.

4.3. Regression Analysis. Simple linear regression analysis shows a significant relationship $(p<0.05)$ between the slope and soil $\mathrm{pH}$ values (Figure 6). The statistical significance suggests an influence of the slope on soil $\mathrm{pH}$ value. As a result, the relationship between the slope and the $\mathrm{pH}$ value suggests that the geomorphometry method is a viable alternative in creating a detailed soil map.

To understand the influence of the slope on the $\mathrm{pH}$ value, an explanation of why a slope condition influences the $\mathrm{pH}$ value is warranted. Slope conditions can influence the distribution of soil, which, in turn, affects the $\mathrm{pH}$ value. The Catena theory suggests the influence of the slope on the soil $\mathrm{pH}$ value. In general, topographic configurations affect soil development through exogenous influences, such as erosion, landslides, weathering, or leaching [38, 64-66]. Additionally, Khan et al. [79] stated that the slope dictates the erosion process, which, in turn, affects both the physical and chemical characteristics of the soil. A study by Tsui et al. (2004) also showed similar results on the chemical properties of the soil. Other approaches, such as geopedology, also mention the relationship between soil characteristics and landform configurations $[12,21]$. 


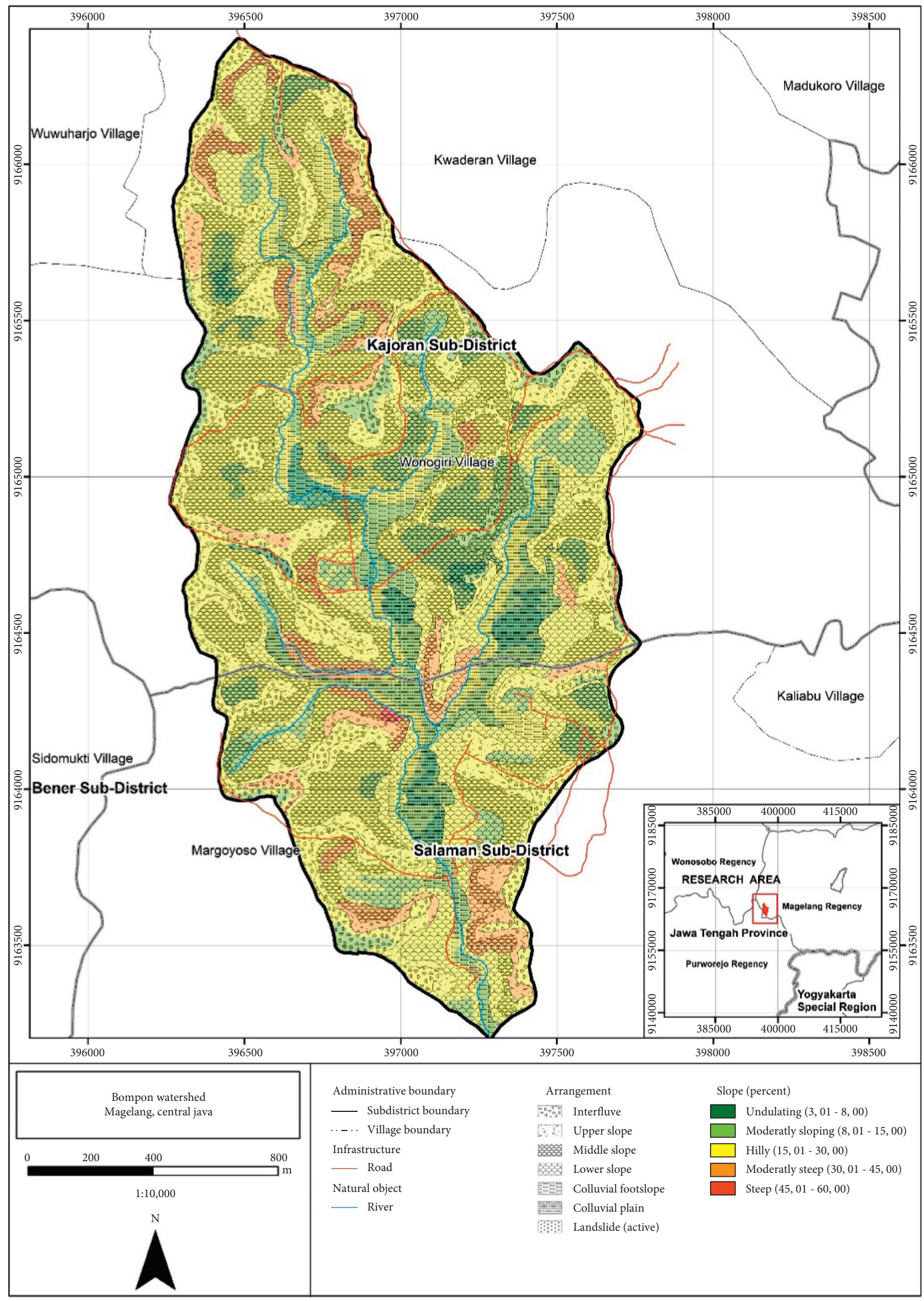

FIGURE 4: Geomorphometry map of Bompon watershed. There are seven classes of the arrangement and five classes of the slope. There is no flat area shown on the map because the proportion is too small and should be generalized. The dominant slope is Hilly, while the middle slope is the dominant arrangement. 


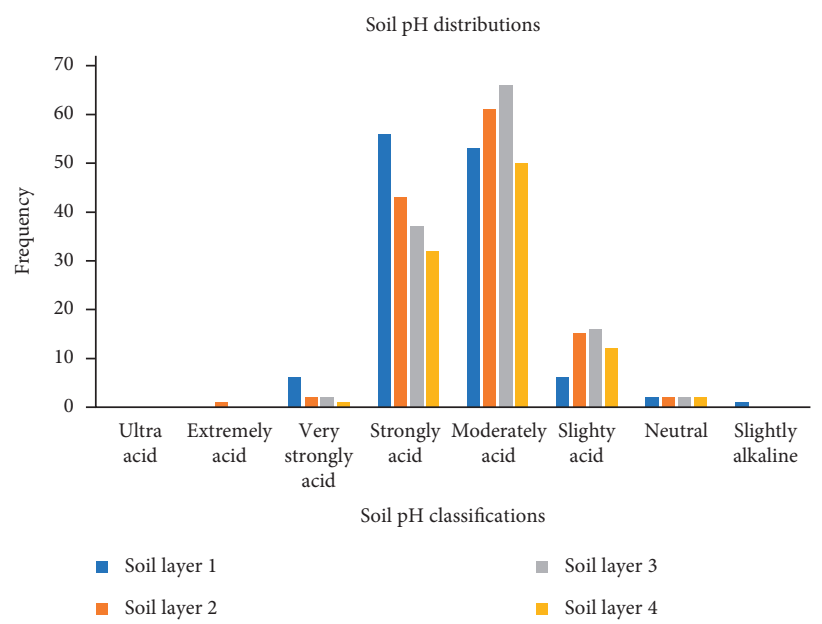

Figure 5: The distributions of soil $\mathrm{pH}$ in Bompon watershed. The dominant classes are moderately acid, followed by strongly acid. This condition is the ideal $\mathrm{pH}$ level of volcanic soil, especially in areas under high rainfall intensity.

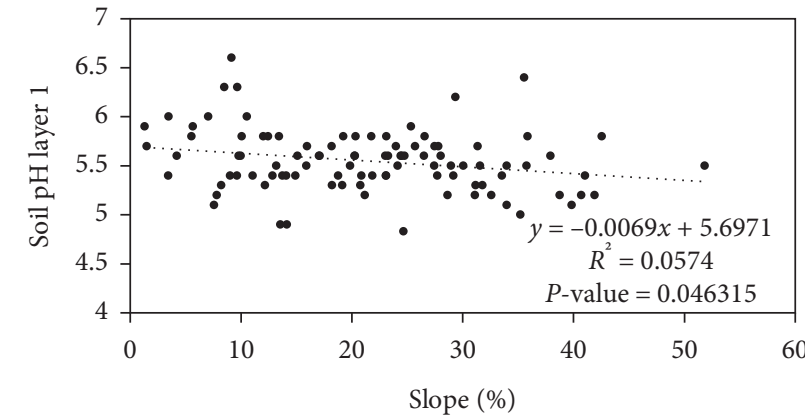

(a)

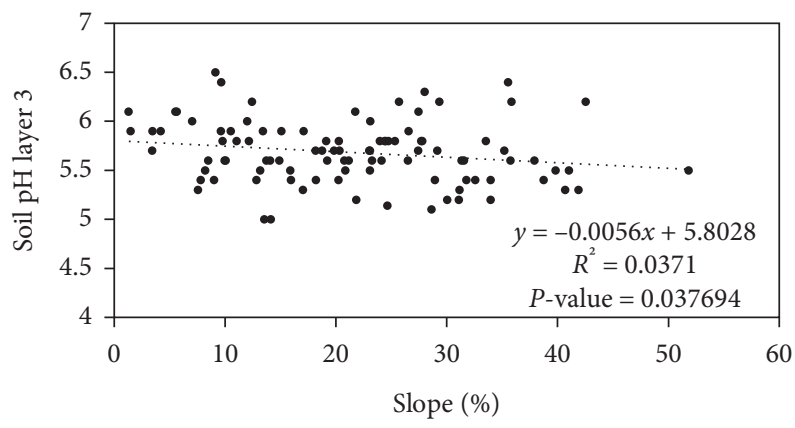

(c)

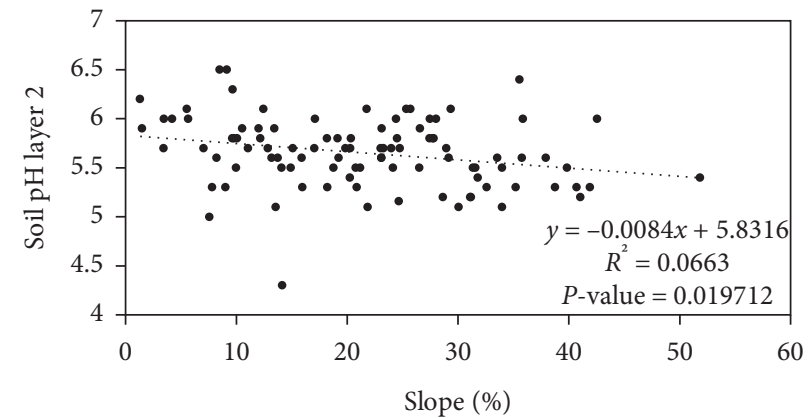

(b)

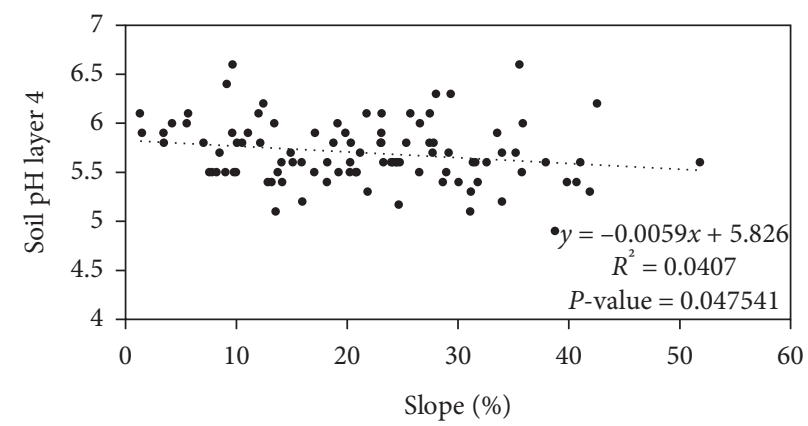

(d)

FiguRe 6: Statistical regression test of soil pH on Bompon watershed on (a) soil layer 1, (b) soil layer 2, (c) soil layer 3, and (d) soil layer 4. All layers have a similar characteristic, significance but still in low $R^{2}$ value.

The coefficient of determination $R^{2}$ shows a low value. $R^{2}$ values across the layers are $0.0321,0.0438,0.0352$, and 0.047 , respectively (Figure 6). Note that low $R^{2}$ does not indicate that the relationship is not valid $[68,69]$. A low $R^{2}$ value is common when there is an unexplainable variation in the dependent variable [82]. Besides, the pvalue test shows a statistical significance. The independent variable still has a strong influence on the dependent variable [82]. Especially in a detailed soil map, a lot of factors, both natural and artificial, could lead to unexplainable variations. Land use and various land modifications can affect soil conditions, including physical and chemical properties [55, 56, 70]. Bakhshandeh et al. and Zajícová and Chuman $[56,71]$ stated that land use has a significant role in changing soil properties, either chemically or physically. A similar condition could happen in the Bompon watershed. The study conducted by Sambodo et al. [32] shows that there are at least 7 main different commodities with different levels of productivity. The intensity of land management carried out in the Bompon watershed is not always controlled by the landform [32, 34]. For example, in the interfluve to colluvial footslope, both cassava plantations and mixed-vegetable 
gardens can be found. The difference in vegetation extremely affects the rate of erosion $[33,72]$. A cassava plantation with relatively open land has a much higher rate of erosion than a mixed-vegetable garden with high vegetation density [33].

Besides the land use, soil clay content also has a significant role in soil $\mathrm{pH}$ conditions in Bompon. The soil in the Bompon watershed has high clay content, mostly above $30 \%$ $[31,32]$. Clay has the smallest particle and smaller pores among different soil textures. These characteristics slow down the movement of the water between each layer of the soil profiles [51]. The high clay soil maintains its characteristics better because of its slower leaching process and a higher CEC rate [75]. Additionally, because of the small size of the watershed, the soil of the entire area shares the same parent material, hydrothermal-altered andesitic volcanic breccia covered with volcanic ashes [25]. The homogeneity in the parent material and the different land-use consideration reduces the influence of geomorphometric factors on the soil properties.

Overall, the statistical regression test showed that there are a lot of factors that could affect the soil $\mathrm{pH}$ on a transitional volcanic landscape, especially for human activities and land use. Unsurprisingly, both factors have a big impact on soil $\mathrm{pH}$ distributions. However, despite the low $R^{2}$ value on each layer, the $p$ value test shows a significant result. It shows that the geomorphometry parameters could explain the general trend of soil $\mathrm{pH}$ conditions in transitional volcanic landform at a detailed scale.

4.4. Cost Comparison. With the geomorphometry method showing a statistical significance result in creating a detailed soil map, the cost-saving associated with using such a method can be compared to the standard grid method. Using the geomorphometric data to make soil mapping units shows significant benefits. The Bompon watershed with an area of 300 hectares requires only 124 sample locations. The number of samples needed far less than using a standard grid method, which would need 811 sample locations. The density of samples taken in the Bompon watershed is 42 samples per square kilometer (Table 4). The number of samples is in an acceptable range for mapping on a scale of $1: 10,000$ [53]. A fewer number of samples reduce the length of time and the amount of personnel needed to conduct a survey.

The economic benefit from using the geomorphometry method can be found by comparing the cost of performing different kinds of surveys. There were 2 survey activities taken in Bompon in 2018 and 2019. The 2018 survey used the grid method, while the 2019 survey used the geomorphometry method. The 2019 survey involved 3 teams, with each team consisting of 3 personnel. Each team finished 5 sampling locations per day on average. The logistics cost was 31 USD daily. Table 5 compares the cost of the two methods. The geomorphometry approach can be performed 7 times faster and reduces the survey cost by a factor of seven. A study by Bazaglia Filho et al. and Kempen et al. $[1,13]$ also shows a similar increase in efficiency by using digital soil mapping instead of the conventional method.
TABle 4: Sampling density for the geomorphometry method per landform arrangements.

\begin{tabular}{lcccc}
\hline Arrangement & Sample & $\begin{array}{c}\text { Area } \\
\text { (hectares) }\end{array}$ & $\begin{array}{c}\text { Sample/ } \\
\text { ha }\end{array}$ & $\begin{array}{c}\text { Sample/ } \\
\mathrm{km}^{2}\end{array}$ \\
\hline Interfluve & 25 & 41.203 & 0.607 & 61 \\
Upperslope & 26 & 44.439 & 0.585 & 59 \\
Middle slope & 37 & 110.295 & 0.335 & 34 \\
Lower slope & 22 & 56.116 & 0.392 & 39 \\
Colluvial & 9 & 20.967 & 0.429 & 43 \\
footslope & 5 & 21.687 & 0.231 & 23 \\
Colluvial plain & 5 & 294.708 & 0.421 & 42 \\
Total & 124 & & & \\
\hline
\end{tabular}

TABLE 5: Cost comparison between geomorphometry approach and conventional grid method. The grid method calculations are based on a survey in 2018.

\begin{tabular}{lcc}
\hline & $\begin{array}{c}\text { Geomorphometry } \\
\text { mapping units }\end{array}$ & $\begin{array}{c}\text { Grid method } \\
(60 \mathrm{~m} \times 60 \mathrm{~m})\end{array}$ \\
\hline $\begin{array}{l}\text { Number of } \\
\text { samples }\end{array}$ & 124 & 811 \\
Number of teams & 3 & 3 \\
Time for survey & 8 & 54 \\
Cost $(1$ & $\$ 256.27$ & $\$ 1,676.07$ \\
USD $=14,500 \mathrm{IDR})$ & $\$ 85.42$ & $\$ 558.69$ \\
Cost $/ \mathrm{km}^{2}$ &
\end{tabular}

However, the use of geomorphometric parameters has a slight challenge in the areas with a high degree of homogeneity. For example, the interfluve region has a much higher sample density compared to the plain colluvial region because the interfluve region which is an erosional region certainly has a more diverse slope configuration than that of the colluvial plain region. Areas with homogenous slope configurations require more samples for the result to be accurate.

\section{Conclusions}

Geomorphometry parameters are useful in creating a detailed soil map at a $1: 10,000$ scale. The regression result shows a statistically significant relationship between the geomorphometry parameters and the soil $\mathrm{pH}$ condition. Furthermore, the geomorphometry approach is less expensive compared to the standard grid method. The geomorphometry method requires 7 times fewer samples. The reduction reduces the cost of performing a survey and makes the geomorphometry method more economical. To improve the accuracy of the result, other parameters such as slope aspects, local relief, slope length, or land use can be included. The increasing availability of affordable remote sensing technology such as drones with various sensors can make it easier to capture more detailed data as well $[67,73,76-78,80,81,83-85]$.

\section{Data Availability}

The data used to support the findings of this study are available from the corresponding author upon request. 


\section{Conflicts of Interest}

The authors declare that they have no conflicts of interest.

\section{Acknowledgments}

The authors would like to thank Professor Junun Sartohadi and Dr. Anggri Setiawan from Universitas Gadjah Mada of Yogyakarta, Indonesia, for the valuable discussion and suggestion during this research. The authors also thank Aries Dwi Wahyu Ramadhana, M.Sc, and Galih Aries Swastanto, M.Sc, of the CV. Geo Art Science, Yogyakarta, Indonesia, for help in arranging permits and equipment. Finally, the authors are also grateful to Rusma Prima Rokhmaningtyas, Surya Sabda Nugraha, Adhera Sukmawijaya, Yuli Widianingsih, and Rachmad Wirawan for their assistance during the fieldwork process. This research was funded by the Thailand Research Fund (Grant no. MRG6280201).

\section{References}

[1] Springer, Digital Soil Mapping with Limited Data, A. E. Hartemink, A. McBratney, and M. de L. MendonçaSantos, Eds., Springer, Dordrecht, Netherlands, 2008.

[2] National Soil Survey Center, Field Book for Describing and Sampling Soils, Government Printing Office, Washington, D.C, USA, 2012.

[3] Soil Science Division Staff, Soil Survey Manual, Government Printing Office, Washington, D.C, USA, 2017.

[4] O. Bazaglia Filho, R. Rizzo, I. F. Lepsch et al., "Comparison between detailed digital and conventional soil maps of an area with complex geology," Revista Brasileira de Ciência do Solo, vol. 37, no. 5, pp. 1136-1148, Oct. 2013.

[5] X. Duan, Y. Xie, T. Ou, and H. Lu, "Effects of soil erosion on long-term soil productivity in the black soil region of northeastern China," CATENA, vol. 87, no. 2, pp. 268-275, 2011.

[6] D. R. Montgomery, "Soil erosion and agricultural sustainability," Proceedings of the National Academy of Sciences, vol. 104, no. 33, pp. 13268-13272, 2007.

[7] F. J. Pierce, W. E. Larson, R. H. Dowdy, and W. A. P. Graham, "Productivity of soils: assessing long-term changes due to erosion," Journal of Soil and Water Conservation, vol. 38, no. 1, pp. 39-44, 1983.

[8] X. Duan, Y. Xie, B. Liu, G. Liu, Y. Feng, and X. Gao, "Soil loss tolerance in the black soil region of Northeast China," Journal of Geographical Sciences, vol. 22, no. 4, pp. 737-751, 2012.

[9] J. P. Gonzalez, S. Cook, T. Oberthur, A. Jarvis, J. A. Bagnell, and M. B. Dias, Creating Low-Cost Soil Maps for Tropical Agriculture using Gaussian Processes, 2007.

[10] A. B. McBratney, M. L. Mendonça Santos, and B. Minasny, "On digital soil mapping," Geoderma, vol. 117, no. 1-2, pp. 3-52, 2003.

[11] G. Szatmári, P. László, K. Takács et al., "Optimization of second-phase sampling for multivariate soil mapping purposes: case study from a wine region, Hungary," Geoderma, vol. 352, pp. 373-384, 2019.

[12] J. A. Zinck, G. Metternicht, G. Bocco, and H. F. Del Valle, Eds., Geopedology, Springer International Publishing, Cham, Switzerland, 2016.

[13] B. Kempen, D. J. Brus, J. J. Stoorvogel, G. B. M. Heuvelink, and F. de Vries, "Efficiency comparison of conventional and digital soil mapping for updating soil maps," Soil Science Society of America Journal, vol. 76, no. 6, pp. 2097-2115, 2012.

[14] T. Hengl, H. I. Reuter, and Institute for Environment and Sustainability (European Commission. Joint Research Centre), Geomorphometry: Concepts, Software, Applications, Elsevier, Amsterdam, Netherlands, 1st ed. edition, 2009.

[15] R. J. Pike, "Geomorphometry -diversity in quantitative surface analysis," Progress in Physical Geography: Earth and Environment, vol. 24, no. 1, pp. 1-20, 2000.

[16] M. J. Smith and C. F. Pain, "Applications of remote sensing in geomorphology," Progress in Physical Geography: Earth and Environment, vol. 33, no. 4, pp. 568-582, 2009.

[17] S. de Bruin and A. Stein, "Soil-landscape modelling using fuzzy c-means clustering of attribute data derived from a Digital Elevation Model (DEM)," Geoderma, vol. 83, no. 1-2, pp. 17-33, 1998.

[18] S. Trevisani, M. Cavalli, and L. Marchi, "Surface texture analysis of a high-resolution DTM: interpreting an alpine basin," Geomorphology, vol. 161-162, pp. 26-39, 2012.

[19] J. A. Viloria, A. Viloria-Botello, M. C. Pineda, and A. Valera, "Digital modelling of landscape and soil in a mountainous region: a neuro-fuzzy approach," Geomorphology, vol. 253, pp. 199-207, 2016.

[20] N. V. Gopp, T. V. Nechaeva, O. A. Savenkov, N. V. Smirnova, and V. V. Smirnov, "The methods of geomorphometry and digital soil mapping for assessing spatial variability in the properties of agrogray soils on a slope," Eurasian Soil Science, vol. 50, no. 1, pp. 20-29, 2017.

[21] I. E. Borujeni, J. Mohammadi, M. H. Salehi, N. Toomanian, and R. M. Poch, "Assessing geopedological soil mapping approach by statistical and geostatistical methods: a case study in the Borujen region, Central Iran," CATENA, vol. 82, no. 1, pp. 1-14, 2010.

[22] D. Kim and Y. Zheng, "Scale-dependent predictability of DEM-based landform attributes for soil spatial variability in a coastal dune system," Geoderma, vol. 164, no. 3-4, pp. 181-194, 2011.

[23] J. C. Richardson, D. M. Hodgson, A. Wilson, J. L. Carrivick, and A. Lang, "Testing the applicability of morphometric characterisation in discordant catchments to ancient landscapes: a case study from southern Africa," Geomorphology, vol. 261, pp. 162-176, 2016.

[24] A. Saldaña, J. J. Ibáñez, and J. A. Zinck, "Soilscape analysis at different scales using pattern indices in the Jarama-Henares interfluve and Henares River valley, Central Spain," Geomorphology, vol. 135, no. 3-4, pp. 284-294, 2011.

[25] N. A. Pulungan and J. Sartohadi, "Variability of soil development in hilly region, bogowonto catchment, Java, Indonesia," International Journal of Soil Science, vol. 13, no. 1, pp. 1-8, 2018.

[26] A. V. Mitusov, L. Burian, and V. R. Khrisanov, "Distribution of local landforms at head and end points of gullies on different grid spacing," CATENA, vol. 159, pp. 159-170, 2017.

[27] G. Louw and A. van Niekerk, "Object-based land surface segmentation scale optimisation: an ill-structured problem," Geomorphology, vol. 327, pp. 377-384, 2019.

[28] A. Prayitno, J. Sartohadi, and M. Nurudin, "Utilization of soil function information for assessing soil quality of rice field in the quaternary-tertiary volcanic transitional zones in central Java," SAINS TANAH-Journal of Soil Science and Agroclimatology, vol. 16, no. 2, p. 169, 2019.

[29] N. A. Pulungan and J. Sartohadi, "New approach to soil formation in the transitional landscape zone: weathering and 
alteration of parent rocks," Journal of Environments, vol. 5, no. 1, pp. 1-7, 2018.

[30] E. S. Pratiwi, J. Sartohadi, and Wahyudi, "Geoelectrical prediction for sliding plane layers of rotational landslide at the volcanic transitional landscapes in Indonesia," IOP Conference Series: Earth and Environmental Science, vol. 286, Article ID 012028, 2019.

[31] Y. Budianto, Keterdapatan Sensitive Clay Pada Lokasi Longsorlahan di DAS Bompon, Kabupaten Magelang, Jawa Tengah, Universitas Gadjah Mada, Yogyakarta, Indonesia, 2016.

[32] A. P. Sambodo, M. A. Setiawan, and R. P. Rokhmaningtyas, "The evaluation of modified productivity index method on the transitional volcanic-tropical landscape," IOP Conference Series: Earth and Environmental Science, vol. 200, Article ID 012011, 2018.

[33] L. O. Hadini, J. Sartohadi, M. Setiawan, and D. Mardiatno, "Characteristics of sediment flow and soil loss of the volcanic landscape watershed with agroforestry landuse," Ecology, Environment and Conservation Paper, vol. 25, no. 3, pp. 1062-1071, 2019.

[34] R. P. Rokhmaningtyas, Estimasi Kehilangan Tanah Aktual Terkait Pengaruh Vegetasi di DAS Bompon, " Universitas Gadjah Mada, Yogyakarta, Indonesia, 2017.

[35] J. Sartohadi, N. A. Harlin Jennie Pulungan, M. Nurudin, and W. Wahyudi, "The ecological perspective of landslides at soils with high clay content in the middle bogowonto watershed, central Java, Indonesia," Applied and Environmental Soil Science, vol. 2018, Article ID 2648185, 9 pages, 2018.

[36] H. Jenny, Factors of Soil Formation: A System of Quantitative Pedology, Dover, New York, NY, USA, 1994.

[37] R. W. Borden, I. C. Baillie, and S. H. Hallett, "The East African contribution to the formalisation of the soil catena concept," CATENA, vol. 185, Article ID 104291, 2020.

[38] K. Teka, J. Nyssen, N. Teha, M. Haile, and J. Deckers, "Soil, land use and landform relationship in the Precambrian lowlands of northern Ethiopia," CATENA, vol. 131, pp. 84-91, 2015.

[39] I. S. Urusevskaya, "Soil catenas on denudation plains in the forest-tundra and northern taiga zones of the Kola Peninsula," Eurasian Soil Science, vol. 50, no. 7, pp. 765-779, 2017.

[40] J. De Reu, J. Bourgeois, M. Bats et al., "Application of the topographic position index to heterogeneous landscapes," Geomorphology, vol. 186, pp. 39-49, 2013.

[41] X. Nie, W. Guo, B. Huang et al., "Effects of soil properties, topography and landform on the understory biomass of a pine forest in a subtropical hilly region," CATENA, vol. 176, pp. 104-111, 2019.

[42] D. Tsozué, J. P. Nghonda, P. Tematio, and S. D. Basga, "Changes in soil properties and soil organic carbon stocks along an elevation gradient at Mount Bambouto, Central Africa," CATENA, vol. 175, pp. 251-262, 2019.

[43] Z.-Q. Yuan, C. Fang, R. Zhang, F.-M. Li, M. M. Javaid, and I. A. Janssens, "Topographic influences on soil properties and aboveground biomass in lucerne-rich vegetation in a semiarid environment," Geoderma, vol. 344, pp. 137-143, 2019.

[44] V. Olaya, "Chapter 6 basic land-surface parameters," Developments in Soil Science, Elsevier, vol. 33, pp. 141-169, , Amsterdam, Netherlands, 2009.

[45] M. Cavalli, B. Goldin, F. Comiti, F. Brardinoni, and L. Marchi, "Assessment of erosion and deposition in steep mountain basins by differencing sequential digital terrain models," Geomorphology, vol. 291, pp. 4-16, 2017.
[46] R. Scalenghe, G. Certini, and F. C. Ugolini, Soils: Basic Concepts and Future Challenges, Cambridge University Press, Cambridge; NY, USA, 2006.

[47] L. Tamene, Z. Adimassu, E. Aynekulu, and T. Yaekob, "Estimating landscape susceptibility to soil erosion using a GISbased approach in Northern Ethiopia," International Soil and Water Conservation Research, vol. 5, no. 3, pp. 221-230, Sep. 2017.

[48] L.-J. Zhu, A.-X. Zhu, C.-Z. Qin, and J.-Z. Liu, "Automatic approach to deriving fuzzy slope positions," Geomorphology, vol. 304, pp. 173-183, 2018.

[49] T. Hengl, "Finding the right pixel size," Computers \& Geosciences, vol. 32, no. 9, pp. 1283-1298, 2006.

[50] Soil Survey Staff, Keys to Soil Taxonomy, USDA-Natural Resources Conservation Service, Washington, DC, USA, 12th ed. edition, 2014.

[51] J. Sartohadi, J. Suratman, and N. I. S. Dewi, Pengantar Geografi Tanah, Pustaka Pelajar, Yogyakarta, Indonesia, 2012.

[52] FAO, Guidelines for Soil Description, Food and Agriculture Organization of the United Nations, Rome, Italy, 4th ed. edition, 2006.

[53] P. Hazelton and B. Murphy, Interpreting Soil Test Results: What Do All the Numbers Mean?, CSIRO Publishing, Clayton, Australia, 2007.

[54] Y. Ge, J. A. Thomasson, and R. Sui, "Remote sensing of soil properties in precision agriculture: a review," Frontiers of Earth Science, vol. 5, 2011.

[55] S. Grunwald, Ed., Environmental Soil-Landscape Modeling: Geographic Information Technologies and Pedometrics, CRC/ Taylor \& Francis, Boca Raton, FL, USA, 2006.

[56] A. Elnaggar and J. Noller, "Application of remote-sensing data and decision-tree analysis to mapping salt-affected soils over large areas," Remote Sensing, vol. 2, no. 1, pp. 151-165, 2009.

[57] E. Eishoeei, H. Nazarnejad, and M. Miryaghoubzadeh, "Temporal soil salinity modeling using SaltMod model in the west side of Urmia hyper saline Lake, Iran," CATENA, vol. 176, pp. 306-314, 2019.

[58] J. Richter, P. R. Owens, Z. Libohova, K. Adhikari, and B. Fuentes, "Mapping parent material as part of a nested approach to soil mapping in the Arkansas River Valley," CATENA, vol. 178, pp. 100-108, 2019.

[59] X. Han, J. Liu, S. Mitra et al., "Selection of optimal scales for soil depth prediction on headwater hillslopes: a modeling approach," CATENA, vol. 163, pp. 257-275, 2018.

[60] F. Shahbazi, P. Hughes, A. B. McBratney, B. Minasny, and B. P. Malone, "Evaluating the spatial and vertical distribution of agriculturally important nutrients-nitrogen, phosphorous and boron-in North West Iran," CATENA, vol. 173, pp. 71-82, 2019.

[61] P. Tsangaratos and I. Ilia, "Comparison of a logistic regression and Naïve Bayes classifier in landslide susceptibility assessments: the influence of models complexity and training dataset size," CATENA, vol. 145, pp. 164-179, 2016.

[62] J. Welsch, C. Songling, H. L. Buckley, N. J. Lehto, E. E. Jones, and B. S. Case, "How many samples? Soil variability affects confidence in the use of common agroecosystem soil indicators," Ecological Indicators, vol. 102, pp. 401-409, 2019.

[63] C.-t. Zhang and Y. Yang, "Can the spatial prediction of soil organic matter be improved by incorporating multiple regression confidence intervals as soft data into BME method?" CATENA, vol. 178, pp. 322-334, 2019.

[64] W. Chesworth, Ed., Encyclopedia of Soil Science: Glossary Terms Included, Springer, Dordrecht, Netherlands, 2008. 
[65] X.-W. Duan, Y. Xie, Y.-J. Feng, and S.-Q. Yin, "Study on the method of soil productivity assessment in black soil region of northeast China," Agricultural Sciences in China, vol. 8, no. 4, pp. 472-481, Apr. 2009.

[66] N. K. Fageria and A. S. Nascente, "Management of soil acidity of south American soils for sustainable crop production," Advances in Agronomy, Elsevier, vol. 128, , pp. 221-275, 2014.

[67] J. Lichty, J. Deenik, A. Kawabata, R. Hamasaki, and S. Nakamoto, Acidification of Volcanic Ash Soils from Maui and Hawaii Island for Blueberry and Tea Production, 2011.

[68] R. Azouzi, A. Charef, S. zaghdoudi et al., "Effect of long-term irrigation with treated wastewater of three soil types on their bulk densities, chemical properties and PAHs content in semiarid climate," Arabian Journal of Geosciences, vol. 9, no. 1, 2016.

[69] E. Bakhshandeh, M. Hossieni, M. Zeraatpisheh, and R. Francaviglia, "Land use change effects on soil quality and biological fertility: a case study in northern Iran," European Journal of Soil Biology, vol. 95, p. 103119, 2019.

[70] V. Ferreira, T. Panagopoulos, A. Cakula, R. Andrade, and A. Arvela, "Predicting soil erosion after land use changes for irrigating agriculture in a large reservoir of southern Portugal," Agriculture and Agricultural Science Procedia, vol. 4, pp. 40-49, 2015.

[71] A. Gupta, Tropical Geomorphology, Cambridge University Press, Cambridge, NY, USA, 2011.

[72] M. Gutiérrez Elorza, Geomorphology, CRC Press/Balkema, Leiden, Netherlands, 2013.

[73] R. J. Huggett, Fundamentals of Geomorphology, Routledge, London, UK, 3rd ed edition, 2011.

[74] R. Navia, G. Hafner, G. Raber, K. E. Lorber, E. Schöffmann, and W. Vortisch, "The use of volcanic soil as mineral landfill liner - I. Physicochemical characterization and comparison with zeolites," Waste Management and Research: The Journal for a Sustainable Circular Economy, vol. 23, no. 3, pp. 249259, 2005.

[75] R. J. Schaetzl and M. L. Thompson, Soils, Cambridge University Press, New York, NY, USA, 2015.

[76] J. L. Richter and C. L. Burras, "Human-impacted catenas in north-central Iowa, United States," Soil Mapping and Process Modeling for Sustainable Land Use Management, Elsevier, Amsterdam, Netherlands, pp. 335-363, 2017.

[77] A. Durak and A. Surucu, "Soil formation on different landscape in a semi-humid region of Turkey," Journal of Agronomy, vol. 4, no. 3, pp. 191-195, 2005.

[78] H. Rezaei, A. A. Jafarzadeh, A. Alijanpour, F. Shahbazi, and K. V. Kamran, "Effect of slope position on soil properties and types along an elevation gradient of arasbaran forest, Iran," International Journal on Advanced Science, Engineering and Information Technology, vol. 5, no. 6, p. 449, 2015.

[79] F. Khan, Z. Hayat, M. Ramzan, Dr. Z. Shah, and M. Hanif, "Effect of slope position on physico-chemical properties of eroded soil," Soil and Enviroment, vol. 31, pp. 22-28, 2013.

[80] C.-C. Tsui, Z.-S. Chen, and C.-F. Hsieh, "Relationships between soil properties and slope position in a lowland rain forest of southern Taiwan," Geoderma, vol. 123, no. 1-2, pp. 131-142, 2004.

[81] R. Bartels, Re-interpreting R-Squared, Regression through the Origin, and Weighted Least Squares, University of Sydney Business School, Darlington, Australia, 2015.

[82] J. Frost, How to Interpret R-Squared in Regression Analysis-Statistics by Jim Statistics by Jim, https://statisticsbyjim. com/regression/interpret-r-squared-regression/, 2020.
[83] T. Bizuhoraho, A. Kayiranga, N. Manirakiza, and K. A. Mourad, "The effect of land use systems on soil properties; A case study from Rwanda," Sustainable Agriculture Research, vol. 7, no. 2, pp. 30-40, 2018.

[84] K. Zajícová and T. Chuman, "Effect of land use on soil chemical properties after 190 years of forest to agricultural land conversion," Soil and Water Research, vol. 14, no. 3, pp. 121-131, 2019.

[85] F. Haghighi, M. Gorji, and M. Shorafa, "A study of the effects of land use changes on soil physical properties and organic matter," Land Degradation and Development, vol. 21, pp. 496-502, 2010. 